\title{
Effect of Alloxan on Insulin and Glucagon Secretion in Perifused Isolated Islets
}

\author{
T. Tomita \\ Department of Pathology and Oncology, University of Kansas Medical Center, Kansas City, Kansas, USA
}

Summary. The effect of alloxan on insulin and glucagon secretion was investigated in perifused isolated rat islets. Five minutes of exposure to $1.4 \mathrm{mmol} / 1$ alloxan in a low-glucose medium $(5.6 \mathrm{mmol} / \mathrm{l})$ abolished subsequent leucine stimulated insulin and glucagon secretion. In a medium containing $19 \mathrm{mmol} / \mathrm{l}$ arginine and $3.3 \mathrm{mmol} / \mathrm{l}$ glucose, insulin secretion was only slightly diminished by alloxan pretreatment, whereas glucagon secretion was reduced to about $60 \%$ of controls. Exposure to alloxan in a high glucose medium $(27.8 \mathrm{mmol} / \mathrm{l})$ did not effect insulin or glucagon secretion.

Key words: Alloxan, isolated islets, perifusion, insulin, glucagon, leucine, arginine, glucose.

Alloxan inhibits glucose-induced insulin secretion in perifused isolated rat islets [1]. Inhibition can be prevented by including insulin-releasing concentrations of glucose in the medium; $\alpha-\mathrm{D}$-glucose gives more protection than $\beta$-D-glucose [2,3]. Alloxan toxicity affects amino acid-stimulated insulin secretion as well [4].

The following effects of alloxan have been observed in isolated rat pancreas [5]: 1) absence of glucose inhibits the subsequent glucose-induced insulin secretion and abolishes the glucose-induced suppression on glucagon secretion. 2) Exposure to alloxan abolishes arginine-stimulated insulin secretion and produces complex effects on glucagon secretion.

In this communication additional evidence is presented which suggests that the glucose receptor system protects against the effect of alloxan on amino acid-stimulated hormone secretion in perifused isolated rat islets.

\section{Materials and Methods}

\section{Isolation of Rat Islets}

For each experiment, 200 islets were isolated from a male SpragueDawley rat $(250-350 \mathrm{~g})$ by the collagenase technique with minor modifications [6]. Briefly, 4-6 mg of collagenase type IV (Worthington) was added to $4 \mathrm{ml}$ of a suspension of minced pancreatic tissue; the mixture was vigorously shaken for $8-10 \mathrm{~min}$ at $37^{\circ} \mathrm{C}$ and then added to an equal volume of Hank's solution. After centrifuging, $4 \mathrm{ml}$ of supernatant was discarded, and the precipitated islets were resuspended in the remainder, and again digested for 2-3 min with no additional collagenase. Each preparation yielded relatively large islets containing a rim of glucagon cells in the outer margin, as visualized in Epon embedded sections by electron microscopy [7].

\section{Perifusion of Isolated Islets}

The perifusion system was identical to that previously reported [ 1 , 3]. Two chambers were perifused simultaneously: one without alloxan served as the control and the other with alloxan exposure as the experimental chamber. Perifusate from each chamber was collected at $1 \mathrm{~min}$ or $5 \mathrm{~min}$ intervals in graded tubes; immediately after collection $500 \mathrm{U}$ of aprotinin (Sigma Chemical) was added per $1 \mathrm{ml}$ of perifusate. Perifusate was collected at 5 min intervals during baseline secretion. Following exposure to alloxan, perifusate was collected at $1 \mathrm{~min}$ intervals for $10 \mathrm{~min}$ to detect the first phase of hormone secretion.

Insulin was determined by radioimmunoassay [8] with pork insulin (Eli Lilly) as the standard.

\section{Glucagon Radioimmunoassay}

Glucagon was radioimmunoassayed with beef-pork glucagon (Eli Lilly, Lot 258-V016-235) as the standard. After adding $0.1 \mathrm{ml}$ of aprotinin $(500 \mathrm{U} / \mathrm{ml})$ and $0.1 \mathrm{ml}$ of diluted rabbit anti-pork glucagon serum (YY 57 kindly supplied by Dr. K. Buchanan and Mr. $\mathrm{R}$. Flanagan, N. Ireland) to each sample $(0.2 \mathrm{ml})$, the tubes were incubated at $4{ }^{\circ} \mathrm{C}$ for $24 \mathrm{~h} .0 .1 \mathrm{ml}$ of tracer $\left[{ }^{125} \mathrm{~T}\right]$ glucagon (New England Nuclear) and $0.1 \mathrm{ml}$ of normal rabbit serum (1:100) as the carrier were then added, and the incubation was allowed to proceed for another $72 \mathrm{~h}$. All of the added solutions were prepared in $0.05 \mathrm{~mol} / 1$ phosphate buffer, pH 7.4 , containing fraction $\mathrm{V}$ 
Table 1. Effect of alloxan on insulin and glucagon secretion

\begin{tabular}{|c|c|c|c|c|c|c|c|}
\hline & 60 min petifusion & $5 \min$ exp & & Insulin secretion & & Glucagon secretion & \\
\hline & & glucose & alloxan & $\mathrm{ng} / 100$ islets $/ 60 \mathrm{~min}$ & Percent secretion & $\mathrm{ng} / 100$ islets $/ 60 \mathrm{~min}$ & Percent secretion \\
\hline & $(\mathrm{mmol} / \mathrm{l})$ & $(\mathrm{mmol} / \mathrm{l})$ & $(\mathrm{mmol} / \mathrm{l})$ & Mean $\pm S E$ & & Mean $\pm \mathrm{SE}$ & \\
\hline I. & Leucine (30.5) & 5.56 & $0(5)^{*}$ & $345 \pm 21$ & $100 \%$ & $11.19 \pm 1.92$ & $100 \%$ \\
\hline & & 5.56 & 1.41 & $169 \pm 29$ & $49 \pm 8^{\mathrm{a} * *}$ & $6.23 \pm 0.56$ & $56 \pm 5^{\mathrm{c}}$ \\
\hline II. & Leucine (30.5) & 27.8 & $0(4)$ & $350 \pm 18$ & $100 \%$ & $9.85 \pm 0.43$ & $100 \%$ \\
\hline & & 27.8 & 1.41 & $328 \pm 18$ & $94 \pm 5^{d}$ & $9.94 \pm 1.33$ & $101 \pm 14^{d}$ \\
\hline III. & Arginine (19)- & 5.56 & $0(7)$ & $345 \pm 19$ & $100 \%$ & $8.40 \pm 0.74$ & $100 \%$ \\
\hline & Glucose (3.33) & 5.56 & 1.41 & $327 \pm 21$ & $95 \pm 6^{0}$ & $5.41 \pm 0.45$ & $64 \pm 5^{b}$ \\
\hline IV. & Arginine (19)- & 27.8 & $0(5)$ & $296 \pm 28$ & $100 \%$ & $8.56 \pm 1.07$ & $100 \%$ \\
\hline & Glucose (3.33) & 27.8 & 1.41 & $303 \pm 6$ & $102 \pm 2^{\mathrm{d}}$ & $7.31 \pm 0.49$ & $85 \pm 6^{\mathrm{d}}$ \\
\hline V. & Arginine (19)- & 5.56 & $0(5)$ & $440 \pm 31$ & $100 \%$ & $8.02 \pm 1.21$ & $100 \%$ \\
\hline & Glucose (11.1) & 5.56 & 1.41 & $300 \pm 40$ & $68 \pm 9^{c}$ & $5.95 \pm 0.87$ & $74 \pm 11^{d}$ \\
\hline VI. & Glucose (11.1) & 5.56 & $0(4)$ & $436 \pm 8$ & $100 \%$ & $3.65 \pm 0.59$ & $100 \%$ \\
\hline & & 5.56 & 1.41 & $133 \pm 9$ & $31 \pm 2^{\mathrm{a}}$ & $4.64 \pm 0.50$ & $127 \pm 14^{d}$ \\
\hline VII. & Leucine (30.5)- & 5.56 & $0(5)$ & $436 \pm 50$ & $100 \%$ & $9.22 \pm 0.67$ & $100 \%$ \\
\hline & $\begin{array}{l}\text { Arginine (19)- } \\
\text { Glucose (3.33) }\end{array}$ & 5.56 & 1.41 & $202 \pm 30$ & $46 \pm 6^{\mathrm{a}}$ & $6.23 \pm 0.47$ & $68 \pm 5^{c}$ \\
\hline
\end{tabular}

* Numbers in parentheses are the numbers of the experiments

** $\mathrm{P}$ values calculated by non-paired $\mathrm{t}$-test

${ }^{\mathrm{a}} \mathrm{p}<0.001 ;{ }^{\mathrm{b}} \mathrm{p}<0.01 ;{ }^{\mathrm{c}} \mathrm{p}<0.05 ;{ }^{\mathrm{d}}$ not significant

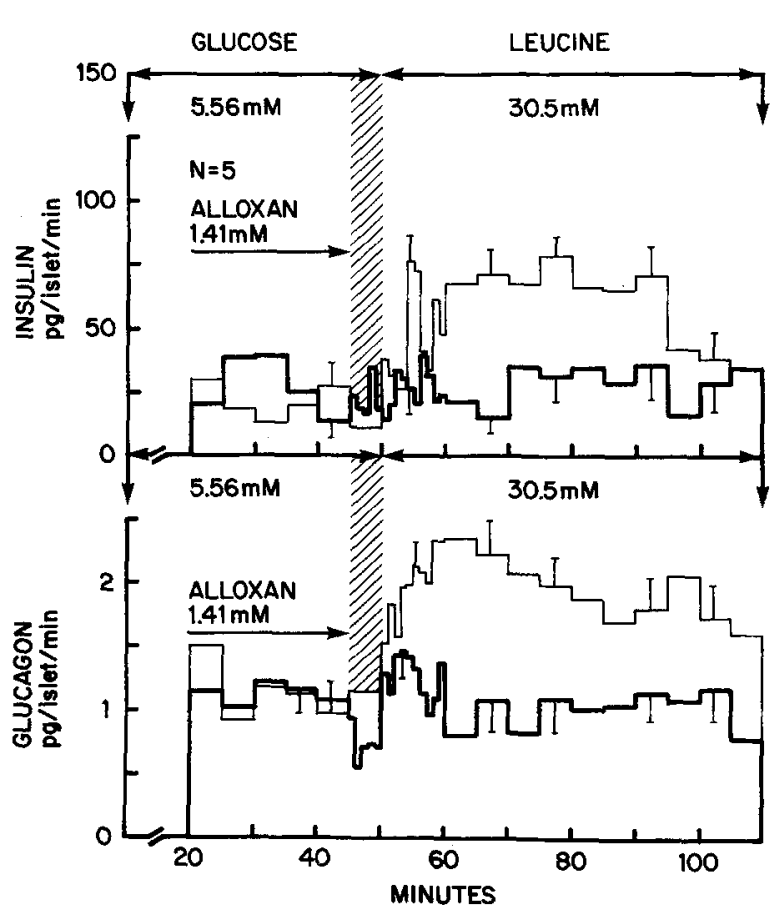

Fig. 1. Test and control islets were perifused simultaneously with $5.6 \mathrm{mmol} / \mathrm{lglucose}$ for $50 \mathrm{~min}$ (control islets) or $45 \mathrm{~min}$ (test islets). The control islets (thin line) were subsequently perifused with $30.5 \mathrm{mmol} / \mathrm{l}$ leucine for $60 \mathrm{~min}$ while the test islets (thick line) were perifused with alloxan and $5.6 \mathrm{mmol} / \mathrm{l}$ glucose for $5 \mathrm{~min}$, and then with $30.5 \mathrm{mmol} / \mathrm{mol}$ leucine for $60 \mathrm{~min}$. Vertical bars indicate standard errors. Upper: Insulin secretion (pg/islet/min) - Lower: Glucagon secretion ( $\mathrm{pg} / \mathrm{islet} / \mathrm{min})$

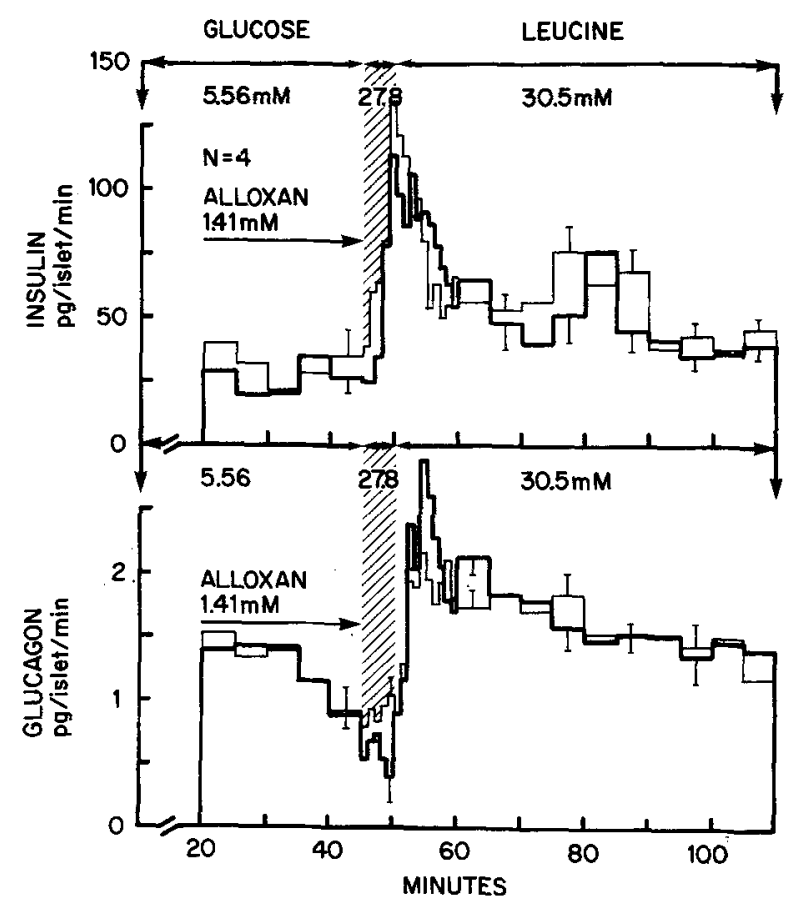

Fig. 2. Test and control islets were perifused with $5.6 \mathrm{mmol} / 1 \mathrm{glu}-$ cose for $45 \mathrm{~min}$. The control islets (thin line) were subsequently perifused with $27.8 \mathrm{mmol} / \mathrm{l}$-glucose for $5 \mathrm{~min}$ and then with $30.5 \mathrm{mmol} / 1$ leucine for $60 \mathrm{~min}$. The test islets (thick line) were perifused with alloxan and $27.8 \mathrm{mmol} / 1$ glucose for $5 \mathrm{~min}$ and then with $30.5 \mathrm{mmol} / \mathrm{l}$ leucine for $60 \mathrm{~min}$. Upper: Insulin secretion (pg/ islet/min) - Lower: Glucagon secretion (pg/islet/min) 


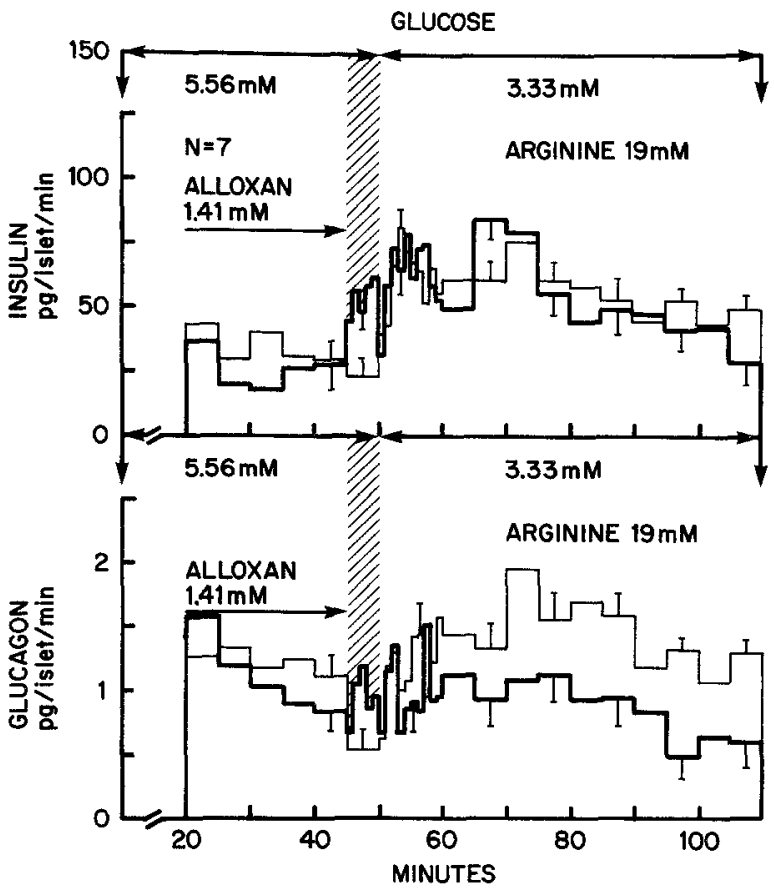

Fig. 3. Test and control islets were perifused with $5.6 \mathrm{mmol} / \mathrm{lglu}$ cose for $50 \mathrm{~min}$ (control) or $45 \mathrm{~min}$ (test). The control islets (thin line) were subsequently perifused with $19 \mathrm{mmol} / 1$ arginine- $\mathrm{HCl}$ plus $3.3 \mathrm{mmol} / 1$ glucose for $60 \mathrm{~min}$. The test islets (thick line) were perifused with alloxan and $5.6 \mathrm{mmol} / 1$ glucose for $5 \mathrm{~min}$ and then with $19 \mathrm{mmol} / 1$ arginine- $\mathrm{HCl}$ plus $3.3 \mathrm{mmol} / 1$ glucose for $60 \mathrm{~min}$. Upper: Insulin secretion (pg/islet/min) - Lower: Glucagon secretion (pg/islet/min)

bovine albumin ( $1 \mathrm{~g} / \mathrm{l}$, Sigma Chemical). Separation of anti-serum bound from free hormone was accomplished by adding $1.2 \mathrm{ml}$ of $99 \%$ isopropyl alcohol followed by centrifugation at $1000 \mathrm{~g}$ for 30 min at $4^{\circ} \mathrm{C}$. The pellets were counted with an automatic gamma system (Searle). The total binding of $\left[{ }^{125} \mathrm{I}\right]$ glucagon after subtracting non-specific binding was $35-55 \%$, and the sensitivity of the radioimmunoassay was $3.4 \mathrm{pg} / 0.2 \mathrm{ml}$.

\section{Results}

\section{Effect of Alloxan on Leucine-stimulated Insulin and Glucagon Secretion}

First phase insulin secretion occurred at about $5 \mathrm{~min}$, and second phase at $15-30 \mathrm{~min}$, after the change to leucine medium in control chambers. In contrast, after pretreatment with alloxan, insulin secretion was not significantly above the baseline ( $40 \mathrm{pg} / \mathrm{min}$, islet). During a $60 \mathrm{~min}$ perifusion the total insulin secretion after alloxan pretreatment was about $50 \%$ of the control secretion (Table 1).

In case of glucagon secretion, two phases of secretion were more difficult to recognize than in the

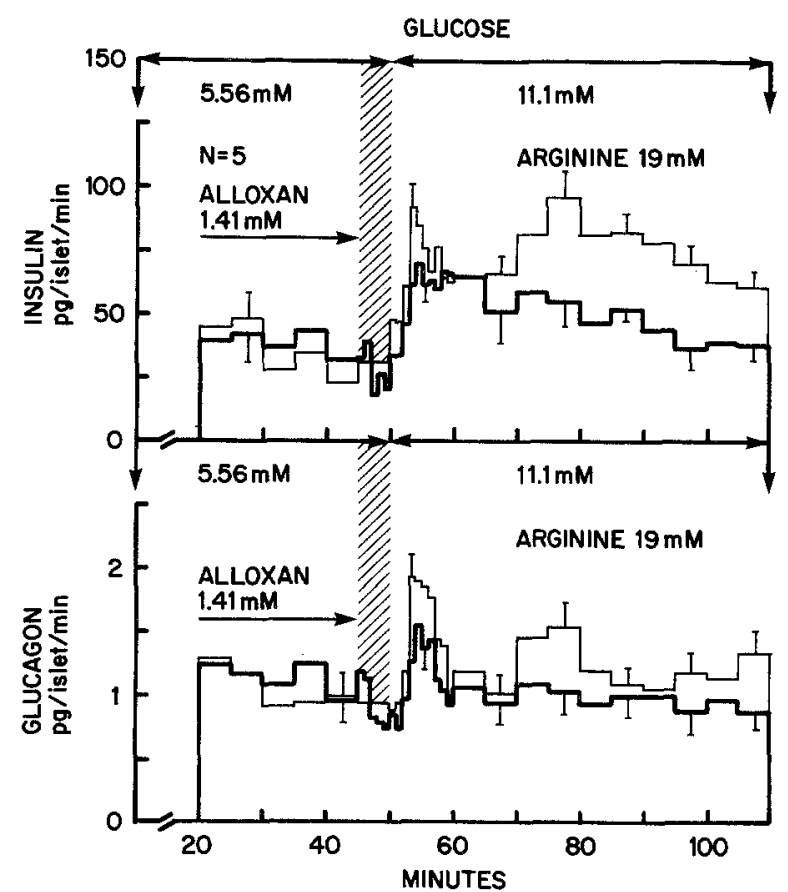

Fig. 4. Test and control islets were perifused with a $5.6 \mathrm{mmol} / 1$ glucose for $50 \mathrm{~min}$ (control) or $45 \mathrm{~min}$ (test). The control islets (thin line) were subsequently perifused with $19 \mathrm{mmol} / \mathrm{l}$ arginine$\mathrm{HCl}$ and $11.1 \mathrm{mmol} / \mathrm{l}$ glucose for $60 \mathrm{~min}$. The test islets (thick line) were perifused with alloxan and $5.6 \mathrm{mmol} / 1$ glucose for $5 \mathrm{~min}$ and then with $19 \mathrm{mmol} / 1$ arginine- $\mathrm{HCl}$ and $11.1 \mathrm{mmol} / 1$ glucose for $60 \mathrm{~min}$. Upper: Insulin secretion (pg/islet/min) - Lower: Glucagon secretion ( $\mathrm{pg} /$ islet/min)

case of insulin secretion (Fig. 1). After alloxan treatment the total glucagon secretion was about $60 \%$ of the control glucagon secretion (Table 1).

The effects of alloxan on leucine-stimulated hormone secretion were not observed when alloxan was added in combination with $27.8 \mathrm{mmol} / 1$ glucose (Fig. 2, Table 1).

\section{Effect of Alloxan on Arginine-stimulated Insulin and Glucagon Secretion}

A mixture of $19 \mathrm{mmol} / \mathrm{l}$ L-arginine- $\mathrm{HCl}$ and $3.3 \mathrm{mmol} / 1$ glucose induced both insulin and glucagon secretion. The insulin secretion occurred in two phases at about $5 \mathrm{~min}$ and at $20-30 \mathrm{~min}$, respectively (Fig. 3). Alloxan pretreatment had no noticeable effect (Fig. 3, Table 1). In contrast, alloxan pretreatment diminished the total glucagon secretion to about $60 \%$ of the control level (Fig. 3, Table 1).

When alloxan was added in the presence of $27.8 \mathrm{mmol} / \mathrm{l}$ glucose, total insulin or glucagon secretion did not differ significantly between control and experimental chambers (Table 1). 


\section{Alloxan Inhibition of Arginine-Glucose (11.1 mmolll) Stimulated Hormone Secretion}

In medium containing $11.1 \mathrm{mmol} / \mathrm{l}$ glucose and $19 \mathrm{mmol} / \mathrm{l}$ arginine distinct first and second phases of insulin and glucagon secretion were observed (Fig. 4). The secretion of insulin, and perhaps also of glucagon, was inhibited by alloxan (Fig. 4, Table 1).

\section{Alloxan Inhibition of Glucose-induced Insulin Secretion}

Alloxan inhibited insulin release in response to $11.1 \mathrm{mmol} / 1$ glucose alone (Table 1). The glucagon release to $11.1 \mathrm{mmol} / \mathrm{l}$ glucose was not significantly influenced by alloxan (Table 1).

\section{Alloxan Inhibition of Hormone Secretion in Response to Leucine and Arginine}

In medium containing a combination of $30.5 \mathrm{mmol} / 1$ leucine, $19 \mathrm{mmol} / 1$ arginine and $3.3 \mathrm{mmol} / 1$ glucose insulin secretion was about the same as in medium containing $11 \mathrm{mmol} / \mathrm{l}$ glucose alone, or arginine plus $11 \mathrm{mmol} / \mathrm{l}$ glucose. Alloxan inhibited insulin secretion to less than one half of that of the controls (Table 1). The level of glucagon secretion was between that obtained by the leucine medium and that seen in the arginine plus glucose $(3.33 \mathrm{mmol} / \mathrm{l})$ medium. It was significantly inhibited by alloxan (Table 1).

\section{Discussion}

Dunn et al. [9] reported that alloxan damage to rat islets was confined to beta cells and that alpha cells were resistant. It is also known that alpha cells are the major surviving component in the islets of long term alloxan diabetic rats [10-12]. From previous [5] and present data, it appears that alloxan affects both beta and alpha cells, at least as regards function in the short-term perspective.

Leucine-stimulated insulin and glucagon secretion was markedly attenuated by alloxan, whereas in the presence of $3.3 \mathrm{mmol} / 1$ glucose the argininestimulated insulin secretion was not (Table 1). However, when insulin secretion was increased by adding $11.1 \mathrm{mmol} / 1$ glucose to the arginine medium, alloxan pretreatment decreased insulin secretion to the rate seen in response to arginine plus $3.3 \mathrm{mmol} / 1$ glucose. Similarly, insulin secretion induced by a mixture of leucine, arginine and $3.3 \mathrm{mmol} / \mathrm{l}$ glucose was reduced by alloxan pretreatment to the rate seen in response to arginine plus $3.3 \mathrm{mmol} / \mathrm{l}$ glucose.
Both insulin cells and glucagon cells appear to possess a glucose-receptor system $[1,13]$ by which glucose stimulates insulin secretion and suppresses glucagon secretion [13]. These receptor systems may somehow be involved in the glucose-induced protection against the effects of alloxan, not only on glucose-induced insulin release but also on leucineinduced insulin and glucagon secretion.

Acknowledgements. This study was in part supported by the Research Grant of the American Diabetes Association and the University of Kansas Medical Center Research Grant. Critical review by Drs. Joe R. Kimmel and Faye Eggerding was gratefully appreciated.

\section{References}

1. Tomita T, Lacy PE, Matschinsky FM (1974) Effect of alloxan on insulin secretion in isolated rat islets perifused in vitro. Diabetes 23: 517-524

2. Niki A, Niki H, Miwa I (1976) Interaction of alloxan and anomers of D-glucose on glucose-induced insulin secretion and biosynthesis in vitro. Diabetes 25: 574-579

3. Tomita T, Kobayashi M (1976) Differential effects of alpha and beta-D-glucose on protection against alloxan toxicity in isolated islets. Biochem Biophy Res Commun 73: 791-798

4. Tomita $T$ (1976) Effect of alloxan on arginine- and leucineinduced insulin secretion in isolated islets. FEBS Lett 72 : $79-82$

5. Goto F, Seino F, Imura H (1978) Modulation by alloxan of glucagon and insulin secretion in the isolated perfused rat pancreas. Endocrinology 102: 1496-1500

6. Lacy PE, Kostianovsky M (1969) Method for the isolation of intact islets of Langerhans from the rat pancreas. Diabetes 16 : 35-39

7. Tomita T, Watanabe I (1976) The effect of alloxan on the permeability of isolated pancreatic islets to horseradish peroxidase. Virchows Arch [Cell Pathol] 22: 217-232

8. Makulu D, Vichick D, Wright PH (1969) Insulin immunoassay by back-titration using alcohol precipitation of insulin-antibody complexes. Diabetes 18: 660-669

9. Dunn JS, Duffy E, Gilmour MD (1944) Further observations on effects of alloxan on the pancreatic islets. J Physiol (Lond) 103: 233-243

10. Hoftiezer V, Carpenter AM (1973) Comparison of streptozotocin and alloxan-induced diabetes in the rat. Diabetologia 9: 178-189

11. Orci L (1976) The microanatomy of the islets of Langerhans. Metabolism 25 (Suppl): 1203-1313

12. Tomita T, Stranahan P (1976) Insulin secretion by isolated islets of alloxan diabetic islets. Virchows Arch [Cell Pathol] 20: 112-123

13. Pagliara AS, Stillings SN, Matschinsky FM (1977) Glucose and 3-0-methylglucose protection against alloxan poisoning of pancreatic alpha and beta cells. Diabetes 26: 973-979

Received: Jüli 23, 1979, and in revised form: March 19, 1980

Tatsuo Tomita, M.D.

Department of Pathology

University of Kansas Medical Center

Kansas City, KS 66103

USA 